\title{
JOHN THELWALL AND THE ORIGINS OF BRITISH SPEECH THERAPY
}

\author{
by \\ DENYSE ROCKEY*
}

\section{SUMMARY}

THIS ARTICLE outlines the social and intellectual forces which led John Thelwall to remedial elocution and to a therapeutic system based upon a largely idiosyncratic view of English prosody. The first section examines those candidates who might challenge Thelwall's claim to having established a new profession and a new science. In the final three sections, Thelwall emerges as an archetypal figure, harmonizing the many facets of speech correction: medicine, linguistics, drama, education, and, more subtly, psychology.

Thelwall first impressed the public mind through politics and, more particularly, oratory, which he intuitively grasped and intellectually understood. This critical interest in the spoken word placed him in the new elocutionary movement which, through its detailed analysis of excellence and its normative prescriptions, throws into contrast abnormal, yet potentially remediable, speech. It is here rather than in deaf education that the orgins of British speech therapy are to be sought.

Thelwall was a practitioner, theorist, and writer. He established an Institute capable of housing residential pupils, plus a number of visitors, drawn there by his lectures and the exhibition of patients. For a time Thelwall flourished, but although he resolved to abandon revolutionary activity its lure continued to claim his attention, to the detriment of his practice and his prosodical treatise, which never came to fruition. Thus, though his logopaedic writings were considerable, indeed unrivalled in their day, the key to his system is missing. If the obscurity of his theory be added to the prejudice generated by his politics, it is easy to see why his ideas were not readily adopted. And paradoxically, the working men's institutes which Thelwall so favoured were partly responsible for trivializing elocution and undermining it as an object of intellectual worth. From this situation contemporary British speech therapy is only just recovering.

\section{INTRODUCTION}

Speech therapy has prompted few historical studies, in contrast to deaf education, with which it is sometimes confused. In Britain, these professions are distinct, their relationships have sometimes been cool, and their boundaries are still ambiguous. ${ }^{1}$

*Denyse Rockey, D.Phil., M.A., L.C.S.T., Linacre College, Oxford. Current address: P.O. Box 1001, Potts Point, Sydney, N.S.W. 2011, Australia.

${ }^{1}$ Department of Education and Science, Speech therapy services, London, H.M.S.O., 1972, pp. 64-66, 120-121. 


\section{John Thelwall and the origins of British speech therapy}

Separation of the two was first advocated by John Thelwall, and, since he was also the first to see remedial elocution ${ }^{2}$ as a specialized occupation, he holds an important place in the history of the handicapped in this country.

British speech therapy is now a small, predominantly female profession. The Cope Report of 1951 recommended that its members be classed as "medical auxiliaries", but objections were raised, not least because speech therapists saw themselves as "poised between education and medicine, claiming affinity with both, defending their independence against both, and enjoying the patronage of neither". ${ }^{3}$ Nevertheless, the fact remains that most therapists work either in hospitals or under the jurisdiction of the Principal School Medical Officer, ${ }^{4}$ and if the Quirk Report's recommendation were to be accepted, their patients would normally be referred by doctors. ${ }^{5}$ Thus, there is in practice a bias towards medicine, though the profession still retains its links with education, drama, psychology, and linguistics.

For historical reasons, speech therapy has come under the medical umbrella, but this was not inevitably its final resting place. Until the eighteenth century, rhetorical studies had academic stature, and had this been maintained and married to physiological inquiry, as Thelwall proposed, speech and its defects might have become part of the university curriculum. The broad sweep of problems would then be open to investigation and practitioners might not fight shy of elective mutism, bilingualism, and foreign accent. Further, the discipline would have been more open to subtle influences from others whose business is also words-orators, poets, and historical philologists.

It is interesting to compare the professional boundaries delineated by Thelwall with those presently prevailing. First, as regards pathology, current practice follows Thelwall's stricture that the deaf and irretrievably idiotic need something other than remedial elocution. Given the technical level of acoustic appliances and the ignorance about mental retardation, this postulate was quite reasonable and derived from his belief that elocution was properly directed towards those who were potentially normal, or at least "improvable". But this led Thelwall to differ from today's therapists in that he saw a logical extension of his activities to provincialisms, foreign accent, and the highest forms of oratory. Thus, his own orientation was broadly founded and essentially normative-embracing "the whole science of delivery, enunciatory and gesticulative". ${ }^{\circ}$ Thelwall was equal to his task, having a mind conversant with rhetoric, poetry, medicine, drama, and linguistics, and having a practical as well as a theoretical grasp of these subjects. However, this was far from the limit of his interests, for he was also an artist, journalist, and political reformer. Elocution was the draw-string gathering together the products of his fertile imagination and eventful life, and consequently it is within a biographical context that the genesis of his "new science" can best be traced. But first, it is necessary to establish whether

\footnotetext{
2 Thelwall spoke simply of elocution. Contemporary titles include speech therapist, speech pathologist, ortholinguist, logopedist. The first is most commonly used in Britain, but is under debate, see ibid., p. 20.

Ibid., pp. 12-13. Cf. ibid., pp. 100-101.

Ibid., p. 33.

Ibid., p. 120.

- Notice, Mthly Mag., 1802, 14: 343-344, p. 344.
} 
there is any justification for Thelwall's claim to novelty, a claim I have gratuitously accepted elsewhere. ${ }^{7}$

\section{PRIORITIES}

Thelwall was certainly not the first to treat or write about speech defects in this country. Previously, their remedy had been attempted by at least two educators of the deaf. John Wallis devised a method of treating malpronunciation, ${ }^{8}$ whilst some years later Henry Baker endeavoured to relieve stammering.' However, speech correction was not the central interest of these men who were, respectively, mathematician and microscopist. Comments on speech impediments are also to be found in a number of medical and elocutionary works, significant amongst which are David Hartley's Observations on man (1749), Erasmus Darwin's Zoonomia (1794), Thomas Sheridan's $A$ course of lectures on elocution (1762), and John Herries' The elements of speech (1773). The passages in question, however, are short and in no way rival Thelwall's 271-page Letter to Henry Cline (1810), which is principally concerned with verbal handicaps.

In addition, there were probably a number of curers using secret remedies, such as the Mr. Angier, whom young Joseph Priestley consulted. ${ }^{10}$ John Walker, like his fellow orthoepist, Thomas Sheridan, may also have tried his hand at speech correction, but this was not on any consistent basis, as those applying to him for help were referred to Thelwall. ${ }^{11}$ Another elocutionist and subscriber to Walker's theory of vocal inflexion was James Wright, but he was born around 1781 and as a young man wrote about the accentual glides of speech rather than its impediments, ${ }^{12}$ his first serious statement on the subject, $A$ treatise on the causes and cure of stuttering, not coming until 1835. Also to be discounted is the Rev. John Evans, who ran a school in the early decades of the nineteenth century, but who openly admitted that some of its features were modelled on Thelwall's Institute. ${ }^{13}$ Indeed, there were only two men who could begin to challenge Thelwall's priority: Benjamin Smart and John Broster.

Although some twenty-nine years Broster's junior, Smart was nevertheless the first to write about speech defects, his $A$ practical grammar of English pronunciation appearing in 1810. This book immediately raised Thelwall's ire. Renaming it "the Grammar of Impediment, or an Essay towards the Art of teaching people how to

'Denyse Rockey, 'The logopaedic thought of John Thelwall, 1764-1834: first British speech therapist', Br. J. Dis. Comm., 1977, 12: 83-95.

- John Thelwall, 'On difficulty of speech', Med. Phys. J., 1806, 15: 172-175, pp. 172-173.

- William Wilde, Practical observations on aural surgery, London, John Churchill, 1853, pp. 446447; G. L'E. Turner, 'Henry Baker, F.R.S.: founder of the Bakerian Lecture', Notes Rec. R. Soc. Lond., 1974, 29: 53-79, p. 58.

${ }^{10}$ Memoirs of Dr. Joseph Priestley (1795), London, H. R. Allenson, 1904, (reprint of the 1809 ed.), pp. 18-19.

${ }^{11} \mathrm{~J}$. Thelwall, 'On the application of the principles of musical proportion in the treatment of impediments of speech', Mthly Mag., 1810, 30: 104-108, p. 105.

12 James Wright, letter to Mthly Mag., 1809, 28: 474-475; 1810, 29: 38-40, 132-134, 30, 417-419.

18 John Evans, The doctrine of philosophical necessity, considered in reference to its tendency, London, Longman, Hurst, Rees \& Orme, 1809, pp. xiii-xiv, 17. I am grateful to Pietro Corsi for this reference and for information regarding the materialistic orientation of many physicians, noted below. Mr. Corsi is making a special study of this question. 


\section{John Thelwall and the origins of British speech therapy}

stammer", 14 he dissociated himself from the sections on stammering whilst simultaneously accusing Smart of plagiarizing other parts. Thelwall pointed out that he had been lecturing publicly since 1802 and had made no secret of his ideas, though he had been unable to commit them all to paper. ${ }^{15}$ Smart admitted attendance at one lecture, ${ }^{16}$ but denied recalling anything but the "mode of delivery" and claimed his own work was based entirely upon Walker, Sheridan, Herries, Nares, and Rice.17 Whatever the rights of this particular issue, Thelwall's publications on impediments were certainly more authoritative and extensive, which is not surprising, as Smart's interests were chiefly philological. Moreover, he was still a teenager when Thelwall began sketching his elocutionary theory.

Broster is a more enigmatic character, often described as a quack on account of his secrecy. This fact would debar him from a place in the intellectual history of speech pathology, but as a social force he cannot be so readily dismissed, since the Rev. Charles Plumptre, an influential Victorian elocutionist, related that Broster was the instigator of Thelwall's career. Plumptre states that Broster's own elocutionary activities began after he had acquired a "great secret" from a fellow actor, the notable tragedian, George Frederick Cooke. Cooke, penniless and ostracized from society due to his scandalous life, fled to America where, in gratitude for Broster's loyal friendship, he gave him his only remaining asset-the key to his melodious and untiring voice. This turned out to be nothing more than a habit of always breathing through the nose, but when Broster returned to England he was able to charge highly for this information and became a rich man. Shortly before his death, after the 1794 treason trials, Broster imparted this secret to his "friend" John Thelwall, who consequently relinquished his political aspirations and took up elocution, passing the secret on to his son in due course. ${ }^{18}$

Had it not been furthered by so respectable a source, this fanciful tale would hardly be worth countering. Apart from it being entirely out of character for Thelwall to condone secrecy and rely upon others for his ideas, there was no possibility of his receiving the secret before Broster's death since this did not occur until 1841, , $^{10}$ seven years after Thelwall's own demise. Furthermore, Broster's Progress of the system for the effectual removal of impediments in speech appeared in 1826, a quarter of a century after Thelwall had envisaged his new science. Nor can anything in the

14 John Thelwall, Illustrations of English rhythmus, London, 1812, p. iv.

${ }^{15}$ Thelwall, Mthly Mag., 30: 104-107; letter, ibid., 1810, 30: 301-303.

10 B. H. Smart, letter, ibid., 1810, 30: 223-225.

${ }^{17}$ B. H. Smart, $A$ grammar of English sounds, London, 1812, pp. iv-v.

18 Charles John Plumptre, King's College lectures on elocution, London, Trübner, new ed., 1883, pp. 72-73. This story does not tally with A. S. Thelwall's comments, also mentioned by Plumptre, in The reading desk and the pulpit, London, Wortheim, MacIntosh, \& Hunt, 1861, which was his inaugural speech at King's College, London. On pp. 44-46, he states that his father had advocated nose breathing from the start and that whatever Broster's secrecy, this rule had been known for at least half a century.

10 Broster's life is almost as obscure as his theory. He is thought to have been born in 1757 and was an alderman of Chester. The facts are difficult to establish because there appear to be three family members having the same name. For a probable genealogy see: $D$. Nuttall, 'A history of printing in Chester', J. Chester archeol. Soc., 1967, 54: 37-95, pp. 71-73, 95. It was probably he who, in 1810, partially anticipated the mechanics institutes, see: Thomas Kelly, George Birkbeck, Liverpool University Press, 1957, p. 68. 


\section{Denyse Rockey}

writings of the two men support the story. Broster's publication is little more than a collection of testimonials praising his system whilst carefully shielding it from view; Thelwall's work is closely reasoned, setting out the bounds of the discipline and the principles upon which treatment should be based.

These facts indicate that Thelwall had good reasons for believing that there were aspects of his profession which were novel. While it is not clear what proportion of his energies was devoted to remedial elocution, he appears to have concentrated upon defective utterance, ${ }^{20}$ and to have devoted more time to writing about and treating it than any of his forebears. His particular originality lay in seeing speech pathology as a specialist study embracing a wide range of impediments, in the boundaries he drew, in his association of elocutionary principles with those of medicine, and in believing the former to be an object of science. Despite extensive reading, he had found no-one who hinted at this possibility: "Where is the individual, who", he asked, "has even suspected that Science had any thing to do with the subject".21 Though Thelwall's concept of science does not accord with our modern view, and can only be touched upon in this paper, he does appear to have been the first to seek principles of certitude and to apply these to cases of impediment.

\section{POLITICS AND RHETORIC}

On 28 July 1811, the diarist, Henry Crabb Robinson, and the future poet laureate, Robert Southey, were discussing their mutual friend John Thelwall. In Southey's view, he was "a very good-hearted man" if, also, a "consummate coxcomb". But, he added parenthetically, "we ought never to forget that he was once as near being hanged as possible. And there is great merit in that."22 Thelwall had been arrested in the second week of May 1794, shortly before Pitt repealed Habeas Corpus, partly on his account. The subsequent five months in solitary confinement in the Tower, a spell in the charnel-house at Newgate, plus the trial, marked a watershed in his life, effectively dividing his political and elocutionary enterprises and ultimately turning the impetuous firebrand into an inquiring scientist. Paradoxically, it was in this role that he was really more revolutionary. Many young heads had been turned by recent upheavals in France, and universal suffrage with annual parliaments was their unanjmous cry; but in seeking the "enfranchisement of fettered organs", ${ }^{23}$ Thelwall was almost alone.

Thelwall was born in Covent Garden during 1764. He was the son of a silk merchant, who died when he was eight, leaving the family in difficult straits. Though able to remain at school for another five years, most of his knowledge came through private reading, particularly poetry, history, and philosophy. This devotion to books irritated his mother and added to existing family frictions. Further, it distracted him to the point

\footnotetext{
20 Thomas Sadler (editor), Diary, reminiscences, and correspondence of Henry Crabb Robinson, 3rd ed., London and New York, Macmillan, 1872, p. 37.

21 John Thelwall, 'Introductory discourse on the nature and objects of elocutionary science', bound in various works, e.g. The Trident of Albion, Liverpool, 1805, pp. 5, 11-14.

22 Sadler, op. cit., note 20 above, p. 176.

2 John Thelwall, $A$ letter to Henry Cline, Esq. on imperfect developements of the faculties, mental and moral, as well as constitutional and organic; and on the treatment of impediments of speech, London, 1810, p.9.
} 


\section{John Thelwall and the origins of British speech therapy}

that he was unable to generate enthusiasm for conventional employment. By his early twenties, however, he found he could earn a living through writing and editing a magazine, activities exposing him to the debates of the day.

At this time, groups with revolutionary views were proliferating, much to government consternation. Thelwall soon joined their ranks, his initiation into practical politics coming through the Society for Free Debate. He spoke at Coachmaker's Hall, and amongst those impressed by his speech during 1790 against moves to nullify the progressive voice of the Westminster electorate was Horne Tooke, one of the parliamentary candidates. Tooke took Thelwall under his wing and for a while became his intellectual father and the man to whom he always deferred. ${ }^{24}$ Thus, Thelwall was at the hub of philological influence, for Tooke's Diversions of Purley (1786) dominated the English scene until the 1830s. ${ }^{25}$ Shortly afterwards, Thelwall joined the London Corresponding Society, which was formed by Thomas Hardy in 1792. He was one of its few members with intellectual stature, and he became its leading orator. The Society provided a perfect proving ground for his gifts and he was to be found inflaming the crowds nightly with its doctrines. This was bound to lead to trouble and, after much harassment by government officials and provocation by their spies, he was arrested and charged with treason, along with eleven compatriots, Horne Tooke and Thomas Hardy amongst them. ${ }^{26}$

Thelwall's acquittal at the Old Bailey was marked by the exultation of his supporters. But instead of mending his ways, the only concession he made to the judge's injunction to modify his political activities, was to dress them up as classical history. A cat-and-mouse game with the authorities followed. Informers abounded, and had he not been armed he might have been killed when a press-gang of some ninety men raided his lecture hall in Yarmouth. ${ }^{27}$ Eventually, this life was too much, even for Thelwall. The government had won the first round and the Jacobin revolt was all but extinguished.

As far as his elocutionary career was concerned, Thelwall's notoriety was a doubleedged sword. It served to publicize his new profession by attracting large audiences, but these were sometimes hostile. In Edinburgh, for instance, where some considered him a traitor, certain individuals "confederated" to disrupt proceedings, one man "concealing himself behind a screen" and signalling to the audience, which was in no mood to pay attention to Thelwall's elocutionary message. ${ }^{28}$

For someone wishing to establish a reputation amongst a clientele necessarily from the wealthier classes, the image of a demagogue or insurrectionist was hardly ideal, as Thelwall fully realized. In attempting to reclaim his "station in society",

2 C. Thelwall, The life of John Thelwall, London, John Macrone, 1837, pp. 73-78; John Thelwall, 'Prefatory memoir' in Poems chiefly written in retirement, Hereford, 1801, pp. xxiv-xxv.

${ }^{25}$ Hans Aarsleff, The study of language in England, 1780-1860, Princeton University Press, 1967, pp. 44-114.

${ }^{26}$ For Thelwall's contribution to 'Planting the Tree of Liberty' see: E. P. Thompson, The making of the English working class, London, Gollancz, 1965, pp. 102-185. Thelwall's political troubles are summarized by Paul M. Zall, 'The cool world of Samuel Taylor Coleridge: Citizen John up against the wall', The Wordsworth Circle, 1972, 3: 111-116.

${ }^{27}$ John Thelwall, An appeal to popular opinion, against kidnapping and murder, London, 1796, pp. 20, 24.

20 Mr. Thelwall's letter to Francis Jeffrey Esq., [n.p.], 1803, pp. $\mathrm{x}$-xi and passim. 


\section{Denyse Rockey}

he stressed that he had discarded politics and requested that the "portraiture" of his mind be judged "from the natural features it might exhibit" rather "than from the distorted caricatures" of his enemies. ${ }^{29}$ People, however, do not forget so quickly. He had many hostilities to overcome, which were still persisting in 1810: "some there are ... who, because, fourteen years ago, I was a zealous (or, if they please, an intemperate) advocate of parliamentary reform, and would not have staked the existence of Europe in a war against the French Revolution, continue to be alarmed at my system of Elocution, and my plans for the rescue of my unhappy fellow beings from Idiocy and Eccentric Derangement." ${ }^{30}$ And five years later he was complaining: "It is the destiny of those who meddle in politics, never to have justice done to any other talent or faculty they may possess". ${ }^{31}$ To some extent, Thelwall had only himself to blame. While trying to dismantle the wall of prejudice and divest himself of political associations, he held dinner parties at his Institute for such men as Godwin, Holcroft, Peter Pindar (Dr. Wolcott), Major Cartwright, Crabb Robinson, Lamb, Britton, and Henry Cline, some of whose names were synonymous with the radical cause. ${ }^{32}$

Politics and elocution, therefore, existed in a certain state of tension. For many years elocution took pride of place but in the years after Napoleon's defeat, Thelwall became caught up with the resurgence of political activism, not least of which was the expansion of the radical press. Throwing caution to the wind, he re-entered the political arena, appearing on the hustings during the Westminster elections; appealing to the crowd for the victims of Peterloo; ${ }^{33}$ composing a poem to be read in aid of charity for those made homeless by the recent severe winter. ${ }^{34}$ Then, in 1818 , he purchased The Champion, a political magazine to which Lamb sometimes contributed.

But times had changed. Henry Hunt had assumed the mantle of radical orator; The Champion failed, and Thelwall returned to elocution. He lived to see the passing of the Reform Bill and on 19 June 1832, he was writing to his old friend Francis Place to ensure a place at any celebratory dinner. ${ }^{35}$ This was probably the Great Reform Banquet, at which Haydon's painting shows him sitting next to Birkbeck and opposite Macauley.

Thelwall remained a public speaker till the end, one of his last appearances being at the funeral of Thomas Hardy, where he delivered the panegyric to mourners numbering between 20,000 to 40,000 , a small gathering compared with his heyday, but no mean feat for an aging man without microphones. His own end was much quieter. He was buried in the grounds of the rectory where he died, in Bath, on 17 February $1834,{ }^{36}$ whilst on another elocutionary tour. ${ }^{37}$

20 John Thelwall, letter, Mthly Mag., 1802, 13: 344-347, p. 344.

${ }^{20}$ Thelwall, op. cit., note 23 above, pp. 104-105. Cf. ibid., pp. 16-17.

31 'Diary of an excursion to France', The Courier, 9 September 1814, Letter VIII, p. 3. For attribution of these letters to Thelwall see: 'Henry Crabb Robinson's diary', typescript 4: pt. 1, pp. 258, 267-268.

32 The auto-biography of John Britton, London, 1850, vol. 1, p. 185.

32 Thompson, op. cit., note 26 above, p. 689.

34 The poetical recreations of The Champion, London, Champion Press, 1822, pp. 102-104.

${ }^{25}$ Letter to Francis Place, British Museum, Add. MS., 37,949, 257.

20 Obituary, Bristol Gazette, 20 February 1834.

${ }^{37}$ Advertisements, Bath Chronicle, 6 February 1834 and Bristol Mirror, 4 January 1834. For a report on Thelwall's lecture series see: Bristol Mercury, 11, 18, 25 January, 8 February 1834. 


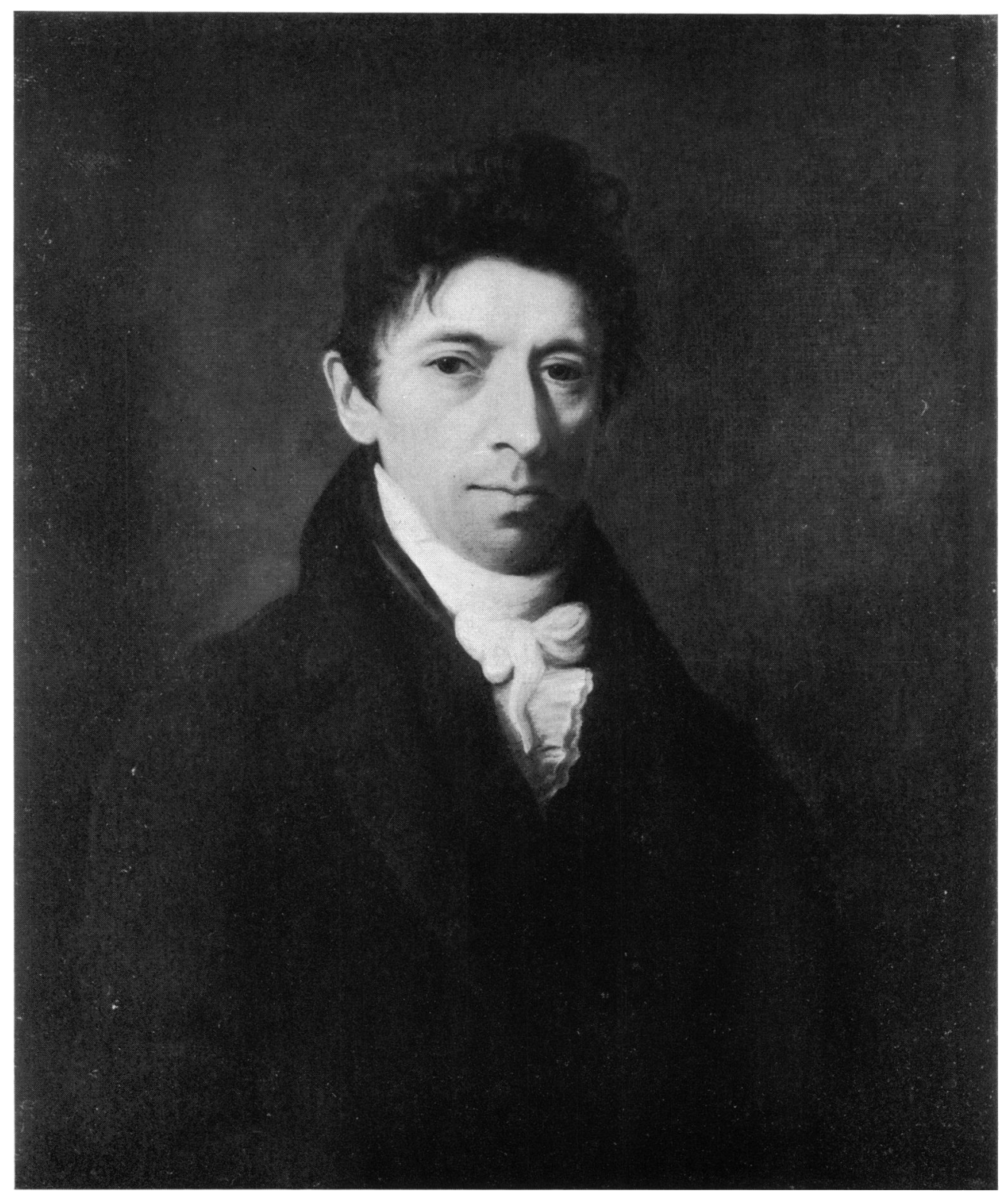

Figure 1.

Photograph of a portrait of John Thelwall by William Hazlitt, now in the National Portrait Gallery, London. 


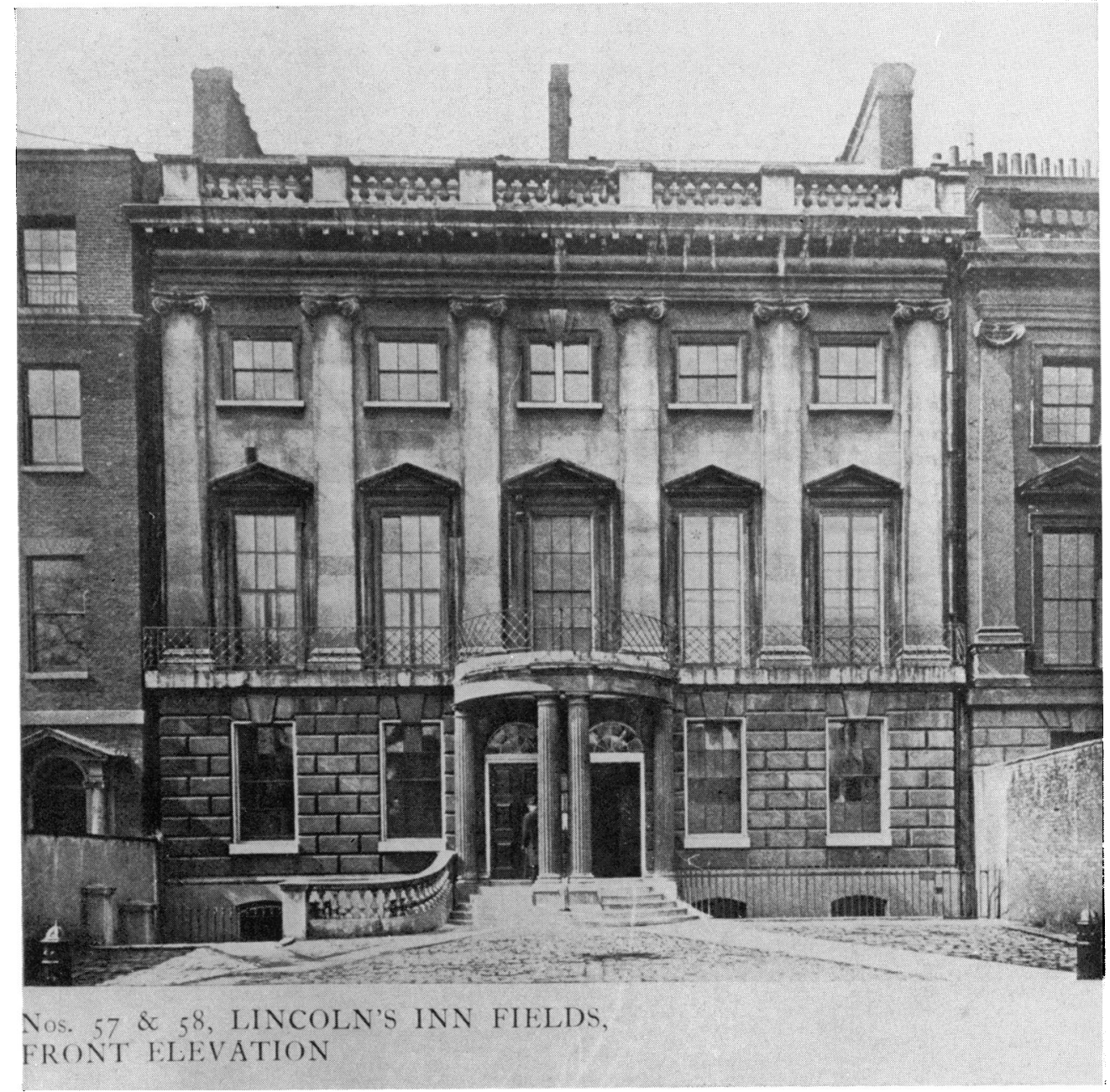

Figure 2.

John Thelwall's principal Institute (no. 57), from the Survey of London, vol. 3, plate 73. 


\section{John Thelwall and the origins of British speech therapy}

Thelwall was amongst the first bringing "eloquence to the masses". ${ }^{88}$ Hazlitt, to whom is attributed a portrait of Thelwall"39 (Fig. 1), described him as the "most dashing orator I ever heard ... a ... thunder-and-lightening mixture". ${ }^{40}$ Whether presenting his political convictions or his elocutionary theory, Thelwall's intent was to persuade, and he seems to have been a master of the art. Persuasion is the essence of rhetoric and entails ideas and arguments clothed in words, arranged in an order and delivered with a confidence and grace which, suitably combined, produce that eloquence appropriate to the moment. The scientific mood of the seventeenth century was out of tune with the roccoco language it had inherited, and successful efforts were made to replace metaphor and other figurative speech with a simple and more exact vocabulary. ${ }^{41}$ The result was a certain severity and drabness which seems to have spilled over into the spoken word, for by the next century delivery had come under attack on account of it being cold, lifeless, and consequently ineffective. The reaction which set in is known as the new elocutionary movement. ${ }^{48}$ It aimed to vivify public speaking and was spearheaded by Thomas Sheridan and John Mason around 1750, though its origins were considerably earlier.43

The movement was characterized by a scientific orientation and hence a search for linguistic and vocal laws, together with notation systems; the most detailed study of delivery yet known, comprehending both speech and gesture; a spirit of independence and originality; a break with tradition, which fostered a new respect for the English language; and an awareness that the diffusion of knowledge was creating a mass audience which called for the popularization of rhetoric through a style that was at once simple and vivid. As if to symbolize this changed attitude, the term elocution, formerly reserved for expression or the style of language, was redefined to signify the style of delivery, the fifth division of classical rhetoric, known previously as pronunciation or action.4

Thelwall was clearly not only part of this movement but one of its driving forces. At the scientific level, his aim was to use words with exactitude and to formulate precise definitions. He also attended to the mechanics of articulation, as is evident from his historical survey of British phonetics, ${ }^{45}$ and the exposition of his own views containing a critique of those of Erasmus Darwin, ${ }^{46}$ whom he had met. Thelwall's

\footnotetext{
88 Lewis Patton and Peter Mann (editors), The collected works of Samuel Taylor Coleridge. Lectures 1795 on politics and religion, Princeton University Press; London, Routledge \& Kegan Paul, 1971, p. xxvi.

20 For reproduction and discussion see: The Connoisseur, 1928, 80: pp. 256, 259.

${ }^{0}$ P. P. Howe (editor), The complete works of William Hazlitt, London, J. M. Dent, 1931, vol. 12, pp. 264-265, identified with Thelwall, vol. 21, p. 207.

"1 Richard Foster Jones et al., The seventeenth century, Stanford and London, Oxford University Press, 1951, pp. 75-110, 111-142, 143-160.

"2 Frederick Haberman, 'English sources of American elocution' in Karl R. Wallace (editor), History of speech education in America, New York, Appleton-Century-Crofts, 1954, pp. 105-129; Wilbur Samuel Howell, Eighteenth century British logic and rhetoric, Princeton University Press, 1971, pp. 144-256.

wilbur Samuel Howell, 'Sources of the elocutionary movement in England: 1700-1748', Quart. J. Speech, 1959. 45: 3-18.

« Haberman, op. cit., note 42 above, pp. 106-113.

45 'Mr. Thelwall's lecture .. . P Panoramic Miscellany, 1826, 1: 41-46 193-198.

46 'Mr. Thelwall's lecture . . . Mthly Mag., 1825, 60: 5-8, 113-117, 202-204, 305-308. For an account of Thelwall's theory see: Robin Thelwall, 'John Thelwall's phonetic theory', in E. J. A.
} 


\section{Denyse Rockey}

preoccupation with laws and mechanistic philosophy has led Haberman to conclude that his concern was only with externals and that he neglected psychology, but this is misleading in view of his instinctive grasp of mass emotions and his understanding of the moral causes of speech defect, particularly in children. ${ }^{77}$ Haberman has a point, however, in arguing that Thelwall, and others in the movement, played a seminal role in such studies as voice training, phonetics, and speech therapy. ${ }^{48}$

It has been said that Thelwall's professional debt was to European educators of the deaf, particularly French, presumably because of their close connexion with speech correction during the nineteenth century. However, such a hypothesis is untenable, not least on account of those to whom the debt might be owed: Abbé de l'Épée, Abbe Sicard, and Dr. Jean Itard, all connected with the Institute for Deaf Mutes in Paris, where dactylology tended to be favoured. Whatever its merits with the deaf, Thelwall believed that speech defectives should be shielded from signing at all costs. He also believed that teaching the deaf did not thereby qualify someone to practise remedial elocution, which was faced by a largely different range of problems. ${ }^{49} \mathrm{Had}$ his ideas derived from Europe, in the early years they would have had to have come through what translations existed, since Thelwall had "no languages" in 1796,50 and though at some point he learnt French, he could not speak Spanish in 1807.51 There seems no evidence to support the assertion of one biographer that he resided in France before going to Wales in the late $1790 \mathrm{~s}^{52}$ However, he was certainly there in 1814, when he observed deaf children in action on several occasions, and also met Sicard and Jeuffroi, whose ideas seem to have been new to him, ${ }^{53}$ but which cannot have been influential since his own theory and practice was by then well established. As for Itard, far from using him as a model, Thelwall believed that he had mishandled the celebrated non-verbal, feral boy of Aveyron, ${ }^{54}$ whom he visited whilst in Paris. ${ }^{55} \mathrm{He}$ also had nothing to learn about stuttering, since Itard's treatise was not published until fifteen years after Thelwall had embarked upon his elocutionary career. Possibly deaf education could have prompted a general idea of helping the verbally handicapped, but biographical evidence suggests otherwise and it is difficult to see what else he could have derived from this source. The deaf were the last people from whom to learn anything about the prosody that was central to his theory. Certainly their problems had contributed to the development of phonetics, but on this score Thelwall would naturally turn to his own language, with its valuable

Henderson, R. E. Asher and W. E. Jones (editors), Studies in the history of phonetics, Edinburgh University Press, forthcoming.

"7 Rockey, op. cit., note 7 above pp. 90-94.

48 Frederick Haberman, 'John Thelwall: his life, his school, his theory', Quart. J. Speech, 1949. 33: 292-298.

- J. Thelwall, letters, Mthly Mag., 1807, 24: 442-445, p. 445; 1808, 25: 202-205; 1809, 28: 2-3, p. 2.

so Warren E. Gibbs 'Unpublished letter from John Thelwall to S. T. Coleridge', Mod. Lang. Rev., 1930, 25: 85-90, p. 89.

61 Thelwall, Mthly Mag., 24: p. 443.

s2 A biographical dictionary of the living authors of Great Britain and Ireland, London, 1816, pp. 343-344.

ss Courier, 7, 14, 15, 20, 26 September, 7 October 1814, letters VII, X, XI, XIII, XVI, XXI.

s4 Rockey, op. cit., note 7 above, p. 93.

ss Courier, 14 September 1814, letter X, p. 3. 


\section{John Thelwall and the origins of British speech therapy}

endogenous tradition. In short, as Thelwall's profession was directed towards the normative aspects of delivery, which took its cue from excellence, not permanent ineptitude, it is reasonable to conclude that British speech therapy, as embodied in him, originated as an off-shoot of the new elocutionary movement and was not a by-product of deaf education, except in so far as each had a common root in John Bulwer.

\section{MEDICINE AND POETRY}

It was not only in philology and articulatory phonetics that Thelwall discerned laws. The body itself was governed by principles, those of the voice being reflected in the muscial aspect of speech, prosody, which was most perfectly expressed in poetry. True harmony was the result of concordance between the natural rhythms of the orovocal musculature and the inherent rhythms, or cadential patterns of the language. Defective utterance, conversely, was largely a legacy of their disunion. ${ }^{56}$ Like many of his contemporaries, Thelwall found no difficulty in straddling such apparently diverse pursuits as medicine and poetry, though he was unusual in applying the former to elocution.

Thelwall's first serious study of science was medicine, possibly prompted by his grandfather, who had been a naval surgeon, ${ }^{57}$ and by Henry Cline, whom he met around 1787, and who proved a loyal friend, both as a defence witness at his trial, ${ }^{58}$ and as a source of referrals and encouragement during his elocutionary career. About five years after their meeting, Thelwall settled near the Borough Hospitals and attended the lectures of Cline, Babington, and Haighton, as well as those of John Hunter. ${ }^{59} \mathrm{He}$ was soon acknowledged as an intellectual light of his group, ${ }^{60}$ amongst whom was the young Astley Cooper, who took an interest in Thelwall's unusual heart condition and asked permission to dissect the organ, should he live the longer. ${ }^{61}$ Around this time, Thelwall also joined the Physical Society of Guy's Hospital, where he made his mark through two papers which characterized his radical and materialistic frame of mind. The latter was not uncommon in medical circles during the early nineteenth century, but Thelwall's position appears to have been more extreme than the majority of his peers found palatable. The first paper, $A n$ essay, towards a definition of animal vitality ... in which several opinions of the celebrated John Hunter are examined and controverted (London, 1793) was debated for five or six evenings. The second, delivered on 14 December 1793, was entitled 'The origin of mental action explained on a system of materialism' and was discussed for three evenings, after which a motion was moved that as it appeared "to have no application to the practice of medicine or surgery", and was therefore of no interest to the society, the discussion be ended. Tumult ensued but eventually the motion was

se Rockey, op. cit., note 7 above, pp. 85-86.

67 Thelwall, 'Memoir' in Poems, op. cit., note 24 above, p. iii.

se John Newton, The trial at large of John Thelwall for high treason, London [n.d.], p. 53, where Cline testifies to knowing Thelwall for seven years, i.e. since 1787. Writing his Letter (op. cit., note 23 above, p. 149) at the end of 1809 Thelwall puts their meeting twenty-five years earlier, i.e. 1784 .

60 C. Thelwall, op. cit., note 24 above, pp. 79-80.

$\infty$ Ibid., p. 79n.

'1 Ibid., p. 80n. When ill, Thelwall's heart beat so loudly that it could be heard across a room or street. One night it awoke his wife, who thought someone was knocking at the door. 


\section{Denyse Rockey}

carried and Thelwall and his supporters withdrew from the society. ${ }^{62}$ In doing so, he parted company with medicine, though he remained on amicable terms with several doctors, who came to look upon him as a specialist capable of helping them out with perplexing patients. At no time did Thelwall view his profession as inferior to theirs, for rhetoric was still prestigious and medicine had yet to establish its now dominating social status. The society's vote might also have shaped his later opinion that doctors had little to offer the verbally handicapped, for implicit in its denial of the relevance of mental action to medicine was a similar denial regarding speech defects, arising as they did from mental and moral causes. ${ }^{63}$

Thelwall left the society early in 1794, the year of his trial. One of his admirers at this time was Samuel Taylor Coleridge, eight years his junior and then a student at Cambridge. The two began to correspond and an intimacy developed which provided Thelwall with much needed rest and friendship; led him to Wales and Kendal, formative points in his elocutionary development; and may have sown the seeds of his prosodical theory.

Thelwall was well equipped to move into Coleridge's literary circle. Poetry had been his first and greatest love and the occasion for some of his happiest moments. ${ }^{64}$ He treasured the idea of becoming one of England's epic poets, ${ }^{65}$ and, though Robinson found this unrealistic, ${ }^{\text {Bb }}$ Wordsworth was not above appropriating some of his lines without acknowledgement, ${ }^{67}$ and both he and Coleridge evidently thought the modulations of Thelwall's "blank verse were superior to that of most writers in that metre". ${ }^{68}$ Thelwall's The peripatetic must also have made an impression for it was on this that The excursion was based. ${ }^{60}$

For Coleridge and Thelwall, poetry provided a unifying bond, disagreeing as they did upon almost everything else. ${ }^{70}$ They exchanged verses, with Thelwall showing himself a critical admirer. ${ }^{11}$ During the halcyon days in Somerset that produced the Lyrical ballads, Coleridge was not only moved to poetic heights but began forging a new metrical form, wherein the number of stresses, rather than syllables, took precedent. Melody was also important, and in The road to Xanadu he offered "music such as had not been heard since Milton wrote Comus". ${ }^{72}$ Since music, rhythm and Milton

es Sir D'Arcy Power, British medical societies, London, Medical Press and Circular, 1939, pp. 24-25; Letter from A. Baster, The Wills Library, Guy's Hospital Medical School, dated 2 March 1978; C. Thelwall, op. cit., note 24 above, p. 104; Thelwall, 'Memoir' in Poems, op. cit., note 24 above, pp. xxii-xxiii, where the second paper is entitled 'On the origin of sensation'.

$\omega$ Rockey, op. cit., note 7 above, p. 90.

a Poetical recreations .... op. cit., note 34 above, p. 115; Thelwall, Mthly Mag., 13: p. 345.

es Ibid., pp. 115, 116, 235-238. Thelwall's epic, The hope of Albion, was conceived in 1798 and had a political theme. The action was consummated by the establishment of an English Constitution on the broad basis of civil and religious liberty.

Wadler, op. cit. note 20 above, p. 37.

17 Ibid., p. 248.

es William Knight, The life of William Wordsworth, Edinburgh, W. Paterson, 1889, vol. 2, p. 364.

- Charles Cestre, John Thelwall, London, Swan Sonnenschein, 1906, pp. 25-29, 195.

70 Earl Leslie Griggs (editor), Collected letters of Samuel Taylor Coleridge, Oxford, Clarendon Press, 1956, vol. 1, p. 339.

71 Gibbs, op. cit., note 50 above, pp. 85-90.

"2 Herbert J. C. Grierson and J. C. Smith, A critical history of English poetry, London, Chatto \& Windus, 1944, p. 313. 


\section{John Thelwall and the origins of British speech therapy}

were especially dear to Thelwall, we may assume that some of his elocutionary ideas derived from this time. According to Omond, Thelwall may have been the vehicle through which Coleridge learned of Joshua Steele's similar rhythmic theory, ${ }^{78}$ but as Thelwall claims no knowledge of Steele before 1802 this is unlikely. ${ }^{74}$ Moreover, Coleridge seems entirely ignorant of the trend of Thelwall's thought during 1803, for he writes to Mrs. Thelwall of her husband's elocutionary lectures: "I could not guess at his System from his Syllabus and my curiosity therefore has still it's [sic] first edge on it". ${ }^{75}$

The story of Thelwall's visit to Nether Stowey, the happy hours he spent with Coleridge, Southey, and the Wordsworths, and of Lamb's sorrow at missing him has often been related. ${ }^{78}$ The spell was short-lived. Wordsworth's odd behaviour was bad enough for local residents, but that Thelwall "whose name was known and hated throughout England" should also join their ranks was unthinkable, and Coleridge had to drop any such plan. ${ }^{77}$ Thelwall was also a persona non grata elsewhere in England, and to avoid further harassment he retreated to a farm in Llys-Wen, ${ }^{78}$ Brecknockshire, possibly prompted by Coleridge's scheme for forming a pantosocratic community in Wales. ${ }^{79}$

The interlude in Wales provided another stepping-stone towards his new career. Thelwall acquired a reputation in the neighbourhood for being something of a "conjuror" and he was therefore approached by a local hatter to help remedy two of his children's unintelligible speech. ${ }^{80}$ Thelwall was happy to oblige and was not entirely inexperienced, for he himself had suffered from a lisp and harsh voice and had had breathing lessons in his youth for weak lungs. ${ }^{81}$

Away from the bustle of revolutionary activities, Thelwall found he could write with ease. ${ }^{82}$ His epic progressed and he produced a novel. Occasionally, he was reminded of his former life by the visit of a spy or the welcome face of a friend. Coleridge, Wordsworth, and Crabb Robinson all visited him. But though Thelwall was a good host, he was no agriculturalist; the harvest was poor, the farm failed, and the family brought to ruin. ${ }^{83} \mathrm{He}$ was now thirty-six and in dire need of subsistence. Worse still, he felt his spirit broken: "the bow had lost its elasticity; it seemed as if its spring was snapped, and it was never to rebound again". ${ }^{84}$ Thelwall's basic optimism prevailed, however, and resolving to "exchange the field of Ceres, for the garden of the Muses" he took to the road again, this time lecturing on elocution.

73 T. S. Omond, English metrists, Oxford, Clarendon Press, 1921, p. 93.

"Thelwall, Mthly Mag., 30: p. 105.

75 Griggs, op. cit., note 70 above, vol. 2, 1017-1019, p. 1018.

76 See, for example: Mrs. Henry Sandford, Thomas Poole and his friends, London, Macmillan, 1888, vol. 1, pp. 204-207, 217-218, 232-243.

"Lawrence Hanson, The life of S. T. Coleridge, early years, London, Allen \& Unwin, 1938, p. 207.

78 For a query over the existence of this place see: Edith J. Morley, The correspondence of Henry Crabb Robinson with the Wordsworth Circle (1808-1866), Oxford, Clarendon Press, 1927, vol. 1 pp. 443-444.

70 Patton and Mann, op. cit., note 38 above, pp. xxv, xli.

so Thelwall, op. cit., note 23 above, pp. 11-13.

81 C. Thelwall, op. cit., note 24 above, pp. 16, 40.

22 Poetical recreations ...., op. cit., note 34 above, p. 116.

83 Thelwall, 'Memoir' in Poems, op. cit., note 24, above, pp. xxxv-xlvi.

84 Thelwall, op. cit., note 23 above, p. 14. 


\section{Denyse Rockey}

The idea had been planted by a friend in Manchester who, on hearing a clergyman delivering elocutionary lectures in the town, thought Thelwall might profitably do likewise. The suggestion burst upon him "in a flood of light". He would use the same title but change the contents and, by a series of "theoretical and practical disquisitions" build "the solid foundations of a permanent and useful profession". ${ }^{85}$ His first tour was in the region of the Trent and Tweed, and, after an experimental period, he extended his sphere of operation to Liverpool, Manchester, and Edinburgh. ${ }^{86} \mathbf{A}$ past-master at playing to the gallery, Thelwall at last found his fortunes changing. With people paying 3 s. $6 \mathrm{~d}$. a ticket, ${ }^{87}$ he might have made $£ 50$ some weeks, as much as he had earned in a year before his trial. He acquired a gig, and was enjoying life. This peripatetic existence was something to which he was well accustomed, but it could hardly have been easy with an expanding family. He therefore took a cue from his friends at Stowey and settled his wife and children in Kendal, a town in which he also lectured.

It was on these tours that Thelwall's mind reflected increasingly upon pathological speech. Doctors would seek his advice about patients whose speechlessness was beyond their expertise. Most important, however, was one particular member of the audience at one of the Kendal lectures-the "blind philosopher", 88 John Gough. Gough both manifested the capabilities of the handicapped and described certain forms of speechlessness, which Thelwall later quoted. Having been blinded by smallpox before the age of three, Gough nevertheless excelled in learning, especially botany and mathematics. For a while, he taught the latter to young John Dalton ${ }^{89}$ and William Whewell; and so acute was his sense of touch that he could recognize plants he knew only through description, never having handled them before. ${ }^{20}$ With feats such as this, it is not surprising that Thelwall came to believe that if "the blind themselves are penetrating" there was no reason why the mute should not have "tongues of fire". 91 That speech defectives could largely master their problem was Thelwall's basic therapeutic tenet, even where physical deformity existed. He pointed to the case of Henry Flood, about whom he had perhaps learned details while on a tour in Ireland. ${ }^{92}$ Flood's mouth was grossly defective, and yet he rose to become a leading orator of his day. ${ }^{23}$ The polish of speech, however, might be lacking, as he suggested was the case with Klopstock, whose enunciation Coleridge reported was unaffected by the lack of upper teeth. $*$ Pursuing this line of reasoning, Thelwall contended that oral malformations were rarely sufficient to produce impediments, which must therefore be ascribed to moral and intellectual causes.

${ }^{85}$ Ibid., p. 16.

" Notice, Mthly Mag., 14: 343-344.

87 Advertisement, York Herald, 2 January 1802.

88 John Kitto, The lost senses, London, Charles Knight, 1845, vol. 2, pp. 214-217.

- D. S. L. Cardwell (editor), John Dalton and the progress of science, Manchester University Press, 1968, pp. xiii, 142-149, 225, 229, 230-231.

${ }^{20}$ Cornelius Nicholson, The annals of Kendal, 2nd ed., London, Whitaker, 1861, pp. 355-368.

.1 J. Thelwall, letter enclosing one to himself from John Gough, Mthly Mag., 1804, 17: 9-11, p. 9.

92 Thelwall refers to his "Lecture Room in Dublin" in a letter to H. Harris, dated 18 November 1817, and possibly he had been there earlier, British Museum, Add MS., 27, 925 , f 56.

'Thelwall, op. cit., note 23 above, p. 74.

" Burton R. Pollin and Redmond Burke, 'John Thelwall's marginalia in a copy of Coleridge's Biographia Literaria', Bull. N.Y. Public Library, 1970, 74: 73-94, p. 92. 


\section{John Thelwall and the origins of British speech therapy}

\section{DRAMA AND EDUCATION}

Alongside the elocutionary movement and associated with it was a renewed interest in the theatre, for which Garrick takes much credit. Under the influence of Walker and Sheridan, theatrical conventions changed and delivery became more animated. ${ }^{95}$ Thus, the new elocutionists' activities extended from persuasion to entertainment, whether this be acting or recitation. Thelwall's passion for drama was long-standing. As an apprentice in his youth he used the tailor's boards for declaiming, and plays were continually in his hands and mouth; he painted scenery; ${ }^{96}$ he thought of the stage as a career, and was devoted to Shakespeare; ${ }^{97}$ he wrote and adapted plays, and endeavoured to get them performed; 98 he took drama students and made critical analyses of leading performers; ${ }^{99}$ he was a friend of Thomas Holcroft, a fellowprisoner in Newgate; 100 he followed the careers of noted actors like Kean and the Siddons; ${ }^{101}$ and whilst in Paris he attended numerous shows, reporting on the relative merits of French and British stage management and performers through the pages of The Courier. Thus, Thelwall began an association between the dramatic and pathological aspects of speech which was continued, through Alexander and Melville Bell to Kate Behnke and the present century, when it became institutionalized, first through the Remedial Section of the Teachers of Speech and Drama, and later in the training programme at the Central School for Speech and Drama, now in Hampstead.

When embarking upon his elocutionary tours, Thelwall was following in the paths of Walker, Sheridan, and his younger relative, James Sheridan Knowles. But recitations could also be more intimate affairs, and he was able to demonstrate his prosodical theory in action at such private gatherings as those hosted by the sociable Lady Cork. His unusual interpretations were not always appreciated, however, one rendering of Milton being judged so absurd that Lady Byron recalls "every body was inclined to laugh". 102

From the start, Thelwall recognized the therapeutic value of drama: articulatory positions were successfully conveyed to the hatter's children "with such mixture of grimace and buffoonery" as was requisite "to impress their rude imaginations". ${ }^{103}$ Other patients displayed their skill and nerve at public exhibitions, for which tickets were issued. ${ }^{104}$ Recitations were individual and choral, ${ }^{105}$ and Crabb Robinson

${ }^{95}$ Haberman, op. cit., note 42 above, p. 108.

88 Thelwall, 'Memoir' in Poems, op. cit., note 24 above, pp. viii, ix.

97 C. Thelwall, op. cit., note 24 above, pp. 13-14.

${ }^{28}$ See: 'The Fairy and the Lake' bound in Thelwall's Poems, op. cit., note 24 above, pp. 1-92; 'The Incas or the Peruvian Virgin' a historical opera attributed to him by Thomas Crofton Crocker, British Museum Add. MS., 38, 622, ff 69-163; letter to Harris, op. cit., note 92 above, concerning the production of Shakespeare's historical plays at Drury Lane; 'Crabb Robinson's diary', op. cit., note 31 above, vol. 5, pp. 293-294, where it reports he had a tragedy before the Committee of Drury Lane in November 1816.

"20 Notice, Mthly Mag., 1807, 23: 265.

100 Thelwall, 'Memoir' in Poems, op. cit., note 24 above, p. xxi.

${ }^{101}$ Thomas Noon Talford, Final memorials of Charles Lamb, London, Edward Moxon, 1848, vol 2, p. 154.

102 'Lady Byron's journal' (MS), 8 June 1811, verso p. 51.

108 Thelwall, op. cit., note 23 above, p. 13.

104 Notice, Mthly Mag., 1807, 23: 581-582.

105 'Further particulars of the public exhibition of pupils at Mr. Thelwall's Institution for the cure of Impediments of Speech', Mthly Mag., 1807, 24: 41-42. 


\section{Denyse Rockey}

records being amused at hearing a troupe of stutterers perform Milton's Comus. These occasions could also be used to repay hospitality, and when Abbe Sicard visited London in 1815, he gave a public demonstration of his own deaf pupils at Thelwall's Institute. ${ }^{106}$ Probably also a visitor at these times was Charles Lamb, who favoured Thelwall's therapeutic efforts, but appears to have made no application of them to his own impediment. ${ }^{107}$ The audience might number sixty or seventy people, and would provide Thelwall with a platform for publicizing his system. In addition, he continued his lecture series on elocution and oratorical criticism, making frequent announcements in the Monthly Magazine, but taking care to stress that the popular topics discussed were only those that did "not necessarily involve any disquisition or considerations of party politics". ${ }^{108}$

Thelwall was a born educator. A man of reason and passion, he could present ideas with a clarity that would generate interest and an enthusiasm that would inspire confidence. In his youth, he had been attracted by Rousseau's doctrines: he believed that the mind should be given free rein and that sensory stimulation was vital. Coleridge had taken issue with him over the former point, drawing a comparison between his "botanical" garden at Stowey (which, being untended was, in reality, a collection of weeds) and Thelwall's own mind. ${ }^{109}$ In practice, however, Thelwall knew exactly what he wanted from patients, who were certainly not encouraged to run wild. But Thelwall's firmness was never punitive. He was committed to Pinel's liberal treatment of the insane and interpretation of the causes of insanity. Aided by an introductory letter from Dr. Davis, who had translated Pinel's Traité médicophilosophique sur l'aliénation mentale (Paris, 1801), he was able to meet Pinel and his assistant Esquirol, who showed him round the Salpetrière and undoubtedly reinforced his own interest in idiocy. ${ }^{110}$

Another admirer of Rousseau was Richard Lovell Edgeworth, and Thelwall fully supported the phonic approach to reading instruction ${ }^{111}$ devised by Edgeworth and his daughter, which, by various symbols, aimed to minimize the difficulties of English orthography. ${ }^{112}$ Maria Edgeworth was, of course, a byword in education, but, through the financial support Thelwall had once been offered by her brother-inlaw, Dr. Beddoes, ${ }^{113}$ she must have had a more personal meaning to him. The two were also common subscribers to the British and Foreign School Society, conducted by the Quaker Joseph Lancaster, ${ }^{114}$ and had a mutual contact in Lady Cork.

As a man particularly wedded to his own theories, it is difficult to tell whether Thelwall was greatly influenced by other ideas touching education. Through Coleridge, a great admirer of Hartley and Priestley, he would have heard much about associationism. He certainly believed that broken associations could underlie speech

\footnotetext{
106 Sadler, op. cit., note 20 above, pp. 257-258, 265; 'Crabb Robinson's diary', op. cit., note 31 above, vol. 4 , pt. 2 , pp. $342-343,345$.

${ }^{107}$ E. V. Lucas, The letters of Charles Lamb, London, J. M. Dent \& Methuen, 1935, vol. 3, p. 20 n.

${ }^{108}$ Notice, Mthly Mag., 1807, 24: p. 381.

100 Griggs, op. cit., note 70 above, vol. 4, p. 880.

110 Courier, 26 September 1814, letter XVI, p. 3.

111 'Mr. Thelwall's lecture ...', op. cit., note 45 above, $1:$ 348-349.

112 Maria and R. L. Edgeworth, Practical education, 2nd ed., London, 1801, vol. 1, pp. 62-73.

113 Griggs, op. cit., note 70 above, vol. 1, p. 382.

111 Ford K. Brown, Fathers of the Victorians, Cambridge University Press, 1961, p. 346.
} 


\section{John Thelwall and the origins of British speech therapy}

impediment, but he elaborated neither on this nor on the role of the faculties that were likewise often at fault. About phrenology he remained silent, partly because his logopaedic writings appeared before 1815 . However, the fact that he permitted reports of the Phrenological Society in his Panoramic Miscellany suggests that he was not totally opposed to it. There is no evidence that Thelwall's pupil, the elocutionist and phrenologist Richard Cull, embraced phrenology whilst under his sway. Thelwall was certainly not averse to using metaphors from craniology, and in admiration of those able to open and close different chambers of their brain at will, he says: "How enviable this spontaneity of command over the different organs of amusiveness, ratiocinativeness, sportiveness, disputativeness, and all the other nesses! But, alas! such command is not ours."115 Phrenology could have been used to support Thelwall's prosodic theory, since it was suggested in an anonymous article that stutterers suffered from a deficiency in the organ of time. ${ }^{116}$ This hypothesis was based on Steele's theory that spoken language is subject to rhythmical pulsations, which Thelwall strongly endorsed. ${ }^{117}$ But whatever his view of the subject, Thelwall fully concurred with the phrenological tenet that education should be suited to each pupil's capabilities.

The possibility of earning a living through teaching had occurred to both Thelwall and Coleridge. Thelwall clearly thought his friend ill-fitted for the task, ${ }^{118}$ but a few months later he was himself considering running a school in conjunction with his wife. Coleridge replied: "I approve of it; and fervently wish, that you may find it more easy of accomplishment, than my fears suggest. But try, by all means, try. Have hopes without expectations-hopes to stimulate exertions, not expectations to hazard disappointment."119 Eight years after receiving this letter, Thelwall opened an Institute in Liverpool. ${ }^{120} \mathrm{He}$ then came to London, taking up residence first in a new house in Bedford Place and then, from 1812 to 1819, in a much larger one in Lincoln's Inn Fields (Fig. 2), for which the rents were $£ 125-£ 150$ and $£ 200$ per annum respectively. ${ }^{121}$ His resumption of journalism and politics was accompanied by further moves. Whilst editing The Champion, he was living at North Brixton Cottage and continuing to see pupils. His next literary venture was The Panoramic Miscellany, a journal he set up in 1826 after his dismissal as editor of The Monthly Magazine, which he had reputedly helped Sir Richard Phillips to launch. ${ }^{122}$ By this time, his address was Dorset Place, Pall Mall East. Between 1832 and 1833 he had established himself at 27 Albany Street, Regent's Park. ${ }^{123}$

It is clear that Thelwall's situation was most stable during the first two decades of the century. His re-entry into public life ate into his energies and finances, but his

116 'The agricultural question', under the signature $\Delta \therefore$, the symbols for thesis and arsis that Thelwall often used, Panoramic Miscellany, 1826, 1: p. 300 .

116 'Observations on the faculty by which we perceive and compare the divisions of duration or time', Phrenological J., 1826-1827, 4: 509-523, pp. 516-517.

${ }_{117}$ Rockey, op. cit., note 7 above, pp. 85-86.

118 Gibbs, op. cit., note 50 above, p. 89.

110 Griggs, op. cit., note 70 above, vol. 1, p. 305.

120 Announcement, Med. Phys. J., 1805, 14 : p. 288.

121 Letter dated 7 October 1975 from Mr. Maidment of St. Pancras Library.

122 A. Boyle, 'Portraiture in Lavengro', Notes and Queries, 1952, 197: 38-39.

123 Survey of London, London, London County Council, 1949, vol. 29, p. 148. The house has been renumbered 54. 


\section{Denyse Rockey}

popularity was already on the wane by November 1818 , when he confided to Crabb Robinson that his Institute had almost come to naught. ${ }^{124}$ But at its height, Thelwall's practice was flourishing. He owned a carriage, ${ }^{125}$ and with a full complement of pupils paying most substantial fees for the time (Table 1), he was able to command an income of $£ 3,000$ a year. ${ }^{126}$

\section{TABLE I}

Thelwall's fees from The poetical recreations of The Champion, pp. vii-viii. For a more detailed breakdown of charges, see his A sketch of the plan and objects of Mr. Thelwall's Institution of Speech . . . Tondon, 1811, pp. 17-32), bound in the British Museum copy of The vestibule of eloquence (London, 1810).

\section{TERMS}

Of instruction to Domestic Pupils, with Impediments or Organic Defects.

(The Fees, for Quarterly, Monthly, or shorter Engagements, to be paid at the time of entrance.)

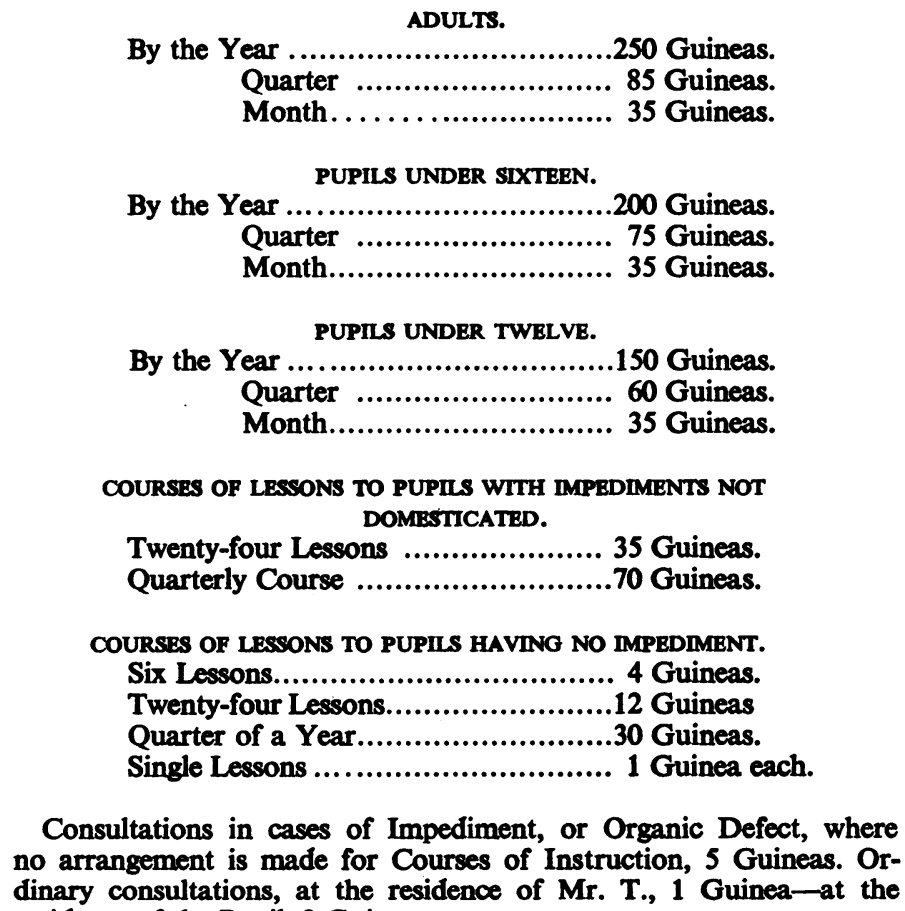

Consultations in cases of Impediment, or Organic Defect, where no arrangement is made for Courses of Instruction, 5 Guineas. Ordinary consultations, at the residence of Mr. T., 1 Guinea-at the residence of the Pupil, 2 Guineas.

124 'Crabb Robinson's diary', op. cit., note 31 above, vol. 4, p. 421.

125 Obituary, Gent. Mag., 1834, 2: 549-550.

126 John Thelwall, Results of experience in the treatment of cases of defective utterance, London, 1814 , p. 55n. 


\section{John Thelwall and the origins of British speech therapy}

In Chapter 42 of Lavengro, George Borrow describes a sixty-year-old elocutionist, famous enough as an orator to have been consulted by Canning. It is not difficult to see why this character has been identified as Thelwall, whom Borrow probably knew through Richard Phillips. With clientele like Canning, Thelwall obviously needed to maintain an air of respectability, and, not wishing to convert his dwelling "into a hospital for idiots and lunatics" or other "disgusting objects", he declined to accept severely impaired patients as house-pupils. ${ }^{127} \mathrm{Mrs}$. Thelwall helped out with the children and young ladies, and in due course his eldest son, Algernon, lent a hand. Thelwall's aim was not merely to improve speech but to foster the highest attainments of learning and refinement, and so instruction was offered in French, Italian, and Latin together with elocution, composition, polite literature, classics, mathematics, and English rhythmus. There was also a history society which met weekly from October to May and was not restricted to pupils, who could therefore enter a wider forum of debate, having prepared themselves with the assistance of Thelwall's three- to four-thousand-volume library. ${ }^{128}$ The polished life, however, called for more than intellectual endowments, so activities were extended to musical appreciation, dancing, and the like. In fact, the curriculum was designed to embrace "every species of erudition and exercise, that can contribute to mental expansion, the dignity and elegance of deportment, and the appropriate graces". ${ }^{120}$

It is ironical that the atheistic Thelwall should have had two sons and many patients who chose to follow a clerical career. The latter involved him with religious writings, and for their benefit he marked passages from the Bible and Church of England Service according to his newly devised notation system. This was a simplification and improvement on Steele's method and was designed to enable cadential reading at sight. ${ }^{130}$ The main repository of knowledge about this system must have been his son, the Rev. Algernon Sydney Thelwall, who was appointed the first lecturer in public speaking at King's College, opened as a Christian establishment to counteract the rather free-thinking London University. Thus, Thelwall's system passed into the hands of clergymen, few of whom were interested principally either in science or in speech correction.

It is also ironical that the elocutionary fashion he helped create should turn from being one of the highest mental and artistic pursuits to merely a diverting pastime. Thelwall himself gave lectures, undoubtedly of quality, at the newly founded Mechanics Institutes and Literary and Philosophical Societies, ${ }^{131}$ and he would surely have welcomed an extension of these courses into a university programme. But the trend was in an opposite direction, for though they continued throughout the century, their function appears to have been increasingly limited to amusement, and the widespread equation of elocution with "idle, bombastic declamation and mannerism" brought it "into disrepute among the grave and learned, and caused the science to

127 Ibid., p. 35.

128 Ibid., Appendix, pp. 6-15; Thelwall, op. cit., note 23 above, pp. 84, 144-147, 249-271;

J. Thelwall, letter, Mthly Mag., 1809, 28: 152-157.

120 Ibid., p. 7.

180 Notice, Mthly Mag., 1807, 23: p. 163.

131 Kelly, op. cit., note 19 above, p. 129; British Museum Add. MS., 27, 824, ff 459, 467. 


\section{Denyse Rockey}

be too generally eschewed as altogether unworthy of intellectual study". ${ }^{132}$ Though a democrat, Thelwall would hardly have condoned such a weakening of its intellectual content, yet he, and the initiators of the elocutionary movement, were partially responsible for its decline, for in striking out from traditional rhetoric they were cutting loose from their academic heritage and setting elocution on the path towards preoccupation with exterior forms and social graces. Those with a serious interest in the subject tried to turn the tide by calling for university chairs to be established: Melville Bell, ${ }^{133}$ Charles Plumptre, ${ }^{134}$ and Browne and Behnke. ${ }^{135}$ Their pleas, however, fell on deaf ears and speech correction moved increasingly towards the practical. This trend was hastened by the early death of James Hunt, in 1869, and the departure to America the following year of Melville and Alexander Graham Bell. Britain had then lost the only men capable of building the discipline into one with the independent stature and breadth of knowledge that Thelwall embodied.

Space does not permit an account of reactions to Thelwall, whose ideas, never understood and never popular, were soon forgotten as new theories took root. ${ }^{136}$ Part of this neglect was his own fault, for while he could found and edit journals, he strangely procrastinated when it came to the elucidation of his system. In 1807, he had stated that many of his theoretical principles could be intelligible to no-one but himself, and we must agree, when he says that "what is new or difficult in the theory, may rather tend to perplex than to inform the student of English prosody". ${ }^{137}$ Granted, busy practitioners are poorly placed to commit their ideas to paper, hence: "those who have the best opportunities of making and ascertaining the validity of useful discoveries, will, pretty generally, be necessitated to suffer their science to perish with them: or, at best, to survive them only in the imperfect remembrance of those to whom it may have been imparted, thro the accident of familiar association." 138 By 1832, he was trying to rectify the situation, but by then he was in no position to finance his own work. On learning of Thelwall's purchasing The Champion, Crabb Robinson feared that "an old age of poverty will be his portion". ${ }^{139}$ Thelwall was not destitute and hoped always to eat "the hard-earned bread of independence", but the paper's collapse nearly bankrupted him. ${ }^{140}$ So the man who, but for his "moral feelings" might have died "loaded with wealth and honour", ${ }^{141}$ was in the position of having to raise money for his project by public subscription. But despite the opportune moment of his appeal, the response was poor. On 20 March, a disappointed

132 Alexander Melville Bell, Observations on speech, Edinburgh, W. P. Kennedy, 1853, pp. 50-51. Cf. Howell, op. cit., note 42 above. pp. 713-714.

183 Ibid., p. 51.

184 Charles John Plumptre, The principles and practice of elocution, Oxford and London, J. H. \& J. Parker, 1861, pp. ix-xi, 2.

125 Lennox Browne and Emile Behnke, Voice, song, and speech, London, Sampson Low, Marston, Searle \& Rivington, 1883, p. 11.

${ }^{126}$ For a review of these see: Denyse Rockey, Stuttering in Britain in the nineteenth century, [tentative title], London, Croom Helm, forthcoming.

187 J. Thelwall, letter, Mthly Mag., 1807, 23: 28-31, p. 31.

188 Thelwall, op. cit., note 23 above, pp. 103-104.

120 Sadler, op. cit., note 20 above, p. 321.

140 Cestre, op. cit., note 69 above, p. 190.

141 Obituary notice, The Times, 19 February 1834, p. 5 


\section{John Thelwall and the origins of British speech therapy}

Thelwall was writing to Place: "I conclude ... that neither my sufferings $\&$ sacrifices in the Political Cause, nor my efforts to advance the Cause of Educational Science can induce the patriots of the day to put their hands in their pockets, in remembrance of one of those but for whose former exertions \& dangers \& continued sacrifices, it is perhaps scarcely presuming arrogance to say-that the cause, in whose honours they are now pluming themsleves, would not at this time have been in its present state of advance."142 What particularly saddened him was the continuing neglect of Sir Francis Burdett, millionaire, philanthropist, and long-time political associate. Thelwall considered he had been "proscribed" and the situation was the more galling since he had recently recommended that Burdett be asked to take the chair at an important forthcoming event. 143

Thelwall had sent circulars to all members of the government, amongst others, and by their response he was unfortunately able to assess "the extent to which liberal feeling accords with the prominent professions of liberalism". Without backing, he accepted that a seal would be put upon expectations that his "system of prosodical Harmonics should ever see the light of day". It did not. Thus Thelwall's two great literary ambitions-his didactic treatise and epic poem-were never realized. But this is not the only touchstone by which his contribution may be judged. He succeeded in helping to plant the tree of liberty amongst the silent masses of his countrymen and he can be credited, also, with igniting a flicker of hope amongst the inarticulate of another order.

\section{ACKNOWLEDGEMENTS}

Permission to reproduce Hazlitt's portrait of Thelwall has kindly been given by the National Portrait Gallery, and to reprint the photograph of his Institute in Lincoln's Inn Fields by The Survey of London, County Hall. Thanks are also due to Dr. Williams's Trust for allowing reference to the typescript of Crabb Robinson's Diary. I am most grateful to Viscount Knebworth and the Earl of Lytton for allowing me to refer to the Lovelace Papers deposited in the Bodleian Library, Oxford.

\footnotetext{
142 John Thelwall, letter to Francis Place dated 20 March 1832, British Museum Add. MS., 37. 950, f 131.

14 John Thelwall, letter to Francis Place, dated 28 October 1832, British Museum Add. MS., 37, 949, ff 291-292.
} 